\title{
Exploring Levels of ICT Adoption and Sustainable Development - The Case of Polish Enterprises
}

\author{
Ewa Ziemba \\ University of Economics in Katowice \\ 1 Maja 50, 40-287 Katowice, Poland \\ ewa.ziemba@ue.katowice.pl
}

\begin{abstract}
This study is a part research on the effect of information and communication technologies (ICT) adoption on sustainable development in the enterprises' context [1]-[3]. Its main purpose is to identify parameters stimulating the progress of ICT adoption and sustainable development and assess the two constructs based on these parameters. The identified parameters of ICT adoption are grouped into four categories i.e., ICT outlay, information culture, ICT management, and ICT quality, whereas the parameters of sustainable development are classified into ecological, economic, sociocultural, and political sustainability categories. This study employs a quantitative approach and descriptive statistics are employed to evaluate the levels of ICT adoption and sustainable development. The survey questionnaire was used and data collected from 394 enterprises were analyzed. The research findings reveal that digital and socio-cultural competences of employees and managers, financial capabilities ensuring ICT projects as well as law regulations associated with ICT adoption, and information security were at the highest level within enterprises. However, the lowest level was specific for BI and ERP system adoption as well as the adoption of latest management concepts and the exploitation of synergies between national ICT projects and own ones. Moreover, the improvement of efficiency and effectiveness of customer services, better and more efficient organization of work, the enhancement of customer satisfaction and loyalty and the acquirement of new customers and markets were at the highest level within enterprises. However, the lowest level was specific for enterprises' participation in the democratic public decision-making as well as energy savings and environmental protection. This study advances ongoing research on ICT adoption and sustainable development by exploring parameters which can be used to describe and assess the levels of ICT adoption and sustainable development in the context of enterprises. Moreover, these parameters help clarify areas that need further improvement and stimulate the progress of ICT adoption and sustainable development.
\end{abstract}

\section{INTRODUCTION}

A new paradigm for economic growth, social equality and environmental protection was set in 1987 and introduced the concept of sustainable development to the international community [4]. Sustainable development is a development in which the needs of present generations are met without compromising the chances of future generations to meet their own needs [5]. According to Schauer [6], sustainable development has four dimensions which are ecological, social, economic and cultural sustainability. Ziemba [1] added a political dimension of sustainable development. Furthermore, it can occur at different levels and within different contexts as many stakeholders on global, national, and community levels are involved in sustainable development [7]. Besides citizens and public administration, enterprises are one of these stakeholders that can contribute to sustainable development and benefit from it [8].

Bisk and Bołtuć [9] highlighted that sustainable development today can best be attained by technological growth, whereas Grunwald [10] assessed the relation between technology and sustainable development as ambivalent. In particular, information and communication technologies (ICT) are a key enabler for sustainable development [11]-[13]. They make significant contributions to revolutionary changes in everyday life, business, and public administration, transforming society and fuelling economic growth. If society stakeholders are unable to acquire the capabilities to adopt ICT effectively, they will be increasingly disadvantaged or even excluded from the benefits afforded by ICT [8]. Some researchers have recognized ICT as one of the most important tools in developing sustainable business practices [14] and supporting the success of businesses [15]. It is contended that ICT enable businesses to improve productivity, foster innovation, cut down costs, increase the effectiveness of processes services, augment the efficiency of business decision-making, react to customer needs at a faster rate, and acquire new ones [16], [14]. Moreover, the ICT adoption by enterprises can gain benefits in environmental preservation by increasing energy efficiency and equipment utilization as well as it can increase information availability to all society stakeholders [6] and as a consequence influence social development [11].

After extensively searching the literature it can be noticed that ICT adoption and sustainable development require indepth research, inter alia, research on assessing the levels of ICT adoption and sustainable development, and indicating areas that should to be improved. We need to have quantitative tools for describing and measuring the state of ICT adoption and sustainable development in the enterprises' context. These tools should allow to define the direction of desirable actions aimed at facilitating sustainable development as a result of ICT adoption.

There are some indicators and synthetic indexes for assessing ICT adoption, e.g. ICT Development Index (IDI) worked out by International Telecommunication Union [17] and Networked Readiness Index (NRI) of the authorship of 
the World Economic Forum [18]. Sets of indicators for measuring sustainable development exist already prepared by Eurostat [19] and OECD [20]. Following an extensive review of the literature, it can be stated that it did not uncover any deep studies providing objective assessment parameters of ICT adoption within enterprises and sustainable development in the enterprises' context. Such parameters would help clarify areas that need further improvement and stimulate the progress of ICT adoption and sustainable development. This paper, therefore, focuses on exploring such parameters. Its aim is to propose parameters describing the progress of ICT adoption and sustainable development and assess the level of ICT adoption and sustainable development based on them.

This paper contributes to the literature in several ways. Section II reviews the current research on ICT adoption within enterprises, sustainable development in the enterprises' context and the assessment of these two constructs. Section III describes the unique research methodology and the data set used for the empirical work. Based on these data, Section IV presents the results, including an assessment of the levels of ICT adoption within enterprises and sustainable development in the enterprises' context. Section V provides the study's contributions, implications, and limitations as well as considerations for future investigative work.

\section{THEORETICAL BACKGROUND AND RESEARCH QUESTION}

\section{A. Sustainable development}

There are multiple definitions of the concept of "sustainable development". The most frequently quoted definition comes from the World Commission on Environment and Development, now known as the Brundtland Commission. According to it, the purpose of sustainable development is to meet "the needs of the present without compromising the ability of future generations to meet their own needs" [21, p. 43]. This definition clarifies the primary essence of the concept: the ability to self-sustain development that does not degrade the factors and mechanisms which constitute it.

Looking more closely into the term "sustainable", it is defined as something that is "able to be upheld or defended" [22]. The definition consists of two distinctive parts; the first one implies that sustainable development is the development that can be retained over time, while the second one indicates that sustainable development is the development that can be shielded from the consequences of negative events and processes. These two parts are closely linked, as it is not only events and processes that may affect development, but the means for development may also augment or create new events and fundamental processes that in turn make the task of maintaining development over time exacting [23]. For instance, our dependency of ICT has allowed for great developmental leaps of many societies since the industrial revolution, but is at the same time the main cause of rising energy consumption and climate change that are now threatening the sole existence of all societies.

The core of the concept of sustainable development embraces two mutually exclusive ideas: the human need to preserve natural resources, and the need to improve the quality of life. Initially, it combined concerns about poverty and development with environmental issues. Then, interpretations of this definition were advanced, ranging from the "pure ecologist" position, through "moderate ecologist," "crash barrier," and "3D," to "4D" [6]. The first two interpretations are purely focused on the ecological dimension. In the "crash barrier" interpretation, the relationship with ecology is weaker, and it places equal weight on social and ecological issues. "3D" defines a further dimension of sustainability, encompassing ecological, social, and economic questions that have equal importance and have to respect each other. In the "4D" approach, cultural dimensions are introduced. Sustainable development is, however, a debatable concept due to its indefinite meaning, which is open to a variety of interpretations, depending upon the given situation [24].

A deeper understanding of the interconnected challenges the world faces allow to recognize that sustainable development has to embrace several sustainability pillars: from the three fundamental pillars related to environmental, economic and social aspects [6], [7] to pillars concerning cultural [25], [26] and political sustainability [25], [27].

This paper defines sustainable development in the enterprises' context as: a dynamic process which enables enterprises to realize their potential and improve their competences and business in ways that simultaneously protect and enhance ecological (Ecl), economic (Eco), sociocultural (Soc), and political (Pol) sustainability.

Ecological sustainability is the ability of enterprises to retain rates of renewable resource acquisition, pollution creation, and non-renewable resource depletion by means of conservation and appropriate use of air, water, and land resources [28], [29]. Economic sustainability of enterprises means that enterprises can obtain competitive advantage, boost their market share, and increase shareholder value by adopting sustainable practices and models. Among the core drivers of a business case for sustainability are: cost and cost reduction, sales and profit margin, reputation and brand value, innovative capabilities [16], [30]. Socio-cultural sustainability is founded on the socio-cultural aspects that need to be sustained e.g., trust, common meaning, diversity as well as capacity for learning and capacity for selforganization [5]. It is perceived as dependent on social networks, making community contributions, creating a sense of place and offering community stability and security [27], [31]. Political sustainability must be built on the basic values of democracy and effective appropriation of all rights. It is connected with the engagement of enterprises in creating democratic society [27]. Based on the stream of research, Ziemba [1] indicated parameters that fully describe those pillars of sustainable development (Table I). 


\section{B. ICT adoption for sustainable development}

ICT represent significant opportunities for sustainable development [11], [12], [32]. The rapid evolution of ICT not only has radically changed of everyday life [33] but also businesses [34]. It has provided enterprises with new instruments to add value to various kinds of sustainability [16], [35].

ICT can be defined as any type of software and hardware used to create, capture, manipulate, communicate, exchange, present, and use information in its various forms" [36, $p$. 198]. Research on ICT adoption is mainly directed to the development of forecasting studies and the identification of barriers and drivers of technology adoption [37]. Reino et al. [37] indicated two main approaches that can be adopted for the study of ICT adoption phenomenon. These are intraenterprise and inter-enterprise adoption. The former relates to the process by which ICT are fully adopted by an enterprise from their purchase to the full integration as part of the business strategy. The latter refers to the phenomena by which ICT adoption take place among an enterprise and its stakeholders as consumers, public administration and other enterprises [38]. It should therefore be acknowledged that ICT adoption takes place in stages and this implies that different levels of ICT adoption can be identified within enterprises.

Furthermore, many investigators, as well as developmental organizations recognize the significance of ICT for sustainable development [6], [11], [35], [39[, [40]. ICT are accelerators, amplifiers, and augmenters of sustainable development. They make it feasible to enhance sustainable development more flexibly and dynamically. More pointedly, ICT presents opportunities to make trade-offs between economic growth, the environment and social cohesion as well as culture and political issues [41]. Equally, there is the opportunity to maximize the social, ecological, economic and cultural opportunities of ICT and mitigate its adverse impacts.

In this study, ICT adoption has been explored in terms of intra-enterprise. Nevertheless, some issues of inter-enterprise adoption have been taken into consideration e.g., related to an enterprise's collaboration with its customers. ICT adoption is understood as the whole spectrum of activities from the period when enterprises justify the need for adopting ICT until the period when enterprises experience the full potential of ICT and derive ecological, economic, socio-cultural and political sustainability from them [1]. The following four pillars of ICT adoption within enterprises are recognized: ICT outlay (Out), information culture (Cul), ICT management (Man), and ICT quality (Qua) [1], [2].

ICT outlay consists of the enterprises' financial capabilities and expenditure on the ICT adoption, as well as funding acquired by enterprises from the European funds. The information culture component encompasses digital and socio-cultural competences of enterprises' employees and managers, constant enhancement of these competences, personal mastery, and incentive systems fostering ICT adoption by employees. The ICT management component embraces the alignment between business and ICT, top management support for ICT projects in the entire ICT adoption lifecycle, implementation of law regulations associated with the ICT adoption, regulations on ICT and information security and protection. The ICT quality component comprises the quality and security of back- and front-office information systems, quality of hardware,

TABLE I.

PARAMETERS OF ICT ADOPTION AND SUSTAINABLE DEVELOPMENT IN THE ENTERPRISES' CONTEXT

\begin{tabular}{|l|l|l|l|l|l|}
\hline \multicolumn{4}{|c}{ Parameters of ICT adoption } & \multicolumn{2}{c|}{ Parameters of sustainable development } \\
\hline Out1 & Financial capabilities & Man16 & ICT project team & Ecl1 & Sustainability in ICT \\
\hline Out2 & Expenditure on ICT & Man17 & Top management support & Ec12 & Sustainability by ICT \\
\hline Out3 & $\begin{array}{l}\text { Funding acquired from the European } \\
\text { funds }\end{array}$ & Man18 & Management concepts adoption & Eco3 & Cost reduction \\
\hline Cul4 & Managers' ICT competences & Man19 & Information security regulations & Eco4 & Sales growth \\
\hline Cul5 & Employees' ICT competences & Man20 & ICT regulations & Eco5 & Product development \\
\hline Cul6 & Managers' permanent education & Man21 & ICT public project & Eco6 & Effective and efficient management \\
\hline Cul7 & Employees' permanent education & Man22 & Competitive ICT market & Eco7 & $\begin{array}{l}\text { Effective and efficient customer } \\
\text { service }\end{array}$ \\
\hline Cul8 & Employees' personal mastery & Qua23 & ICT infrastructure quality & Eco8 & Effective and efficient work \\
\hline Cul9 & $\begin{array}{l}\text { Managers' socio-cultural } \\
\text { competences }\end{array}$ & Qua24 & Back-office system quality & Eco9 & $\begin{array}{l}\text { Acquiring new customers and } \\
\text { markets }\end{array}$ \\
\hline Cul10 & $\begin{array}{l}\text { Employees' socio-cultural } \\
\text { competences }\end{array}$ & Qua25 & Front-office system quality & Eco10 & $\begin{array}{l}\text { Increasing customer } \\
\text { satisfaction/loyalty }\end{array}$ \\
\hline Cul11 & Employees' creativity & Qua26 & Back-office system security & Soc11 & Competence extension \\
\hline Cul12 & Incentive systems & Qua27 & Front-office system security & Soc12 & Working environment improvement \\
\hline Man13 & $\begin{array}{l}\text { Alignment between business } \\
\text { strategy and ICT }\end{array}$ & Qua28 & E-service maturity levels & Soc13 & Increasing security \\
\hline Man14 & Supporting business models by ICT & Qua29 & ERP adoption & Soc14 & Reducing social exclusion \\
\hline Man15 & ICT management procedure & Qua30 & $\begin{array}{l}\text { BI (Business Intelligence) } \\
\text { adoption }\end{array}$ & Pol15 & E-democracy \\
\hline--- & ------ & - & Pol16 & E-public services \\
\hline
\end{tabular}

Source: on the basis of [22]. 
maturity of e-services, and adoption of ERP and BI systems Table I describes each of the above ICT adoption pillars.

\section{Problem identification and research questions}

ICT adoption for sustainable development is not a destination, but a dynamic process of adaptation, learning and action. It is about recognizing, understanding and acting on ICT adoption and sustainable development as well as on interconnections between them.

As mentioned above, in the previous study Ziemba [1] indicated parameters describing the constructs of ICT adoption and sustainable development in the enterprises' context, and then grouped them into appropriate pillars (Table I). ICT adoption embraces ICT outlay, information culture, ICT management and ICT quality, whereas sustainable development includes ecological, economic, socio-cultural and political sustainabilities. Then the quality of the two constructs was assessed by examining the construct reliability [42], convergent validity [43], [44], and discriminant validity [43], [45]. Overall, the results successfully established the reliability as well as convergent and discriminant validity of ICT adoption and sustainable development, and their pillars. Furthermore, the levels of ICT and sustainable development pillars were assessed (Table II) and the approach to the measurement of the two constructs ICT was proposed [3].

\section{RESEARCH METHODOLOGY}

To address the main research problem and answer the research questions a quantitative research approach was adopted. Research methods included a critical review of the literature, logical deduction, a survey questionnaire, and statistical analysis. The research process has been described in the previous works [1], [2] but for the ease of this paper readability and sake of its completeness, it is also presented below.

\section{A. Research instrument}

The Likert-type instrument (survey questionnaire) was developed. Closed-ended questions were specified to collect data regarding the evaluation of the parameters describing:

- The four pillars of ICT adoption i.e., ICT outlay (Out), information culture (Cul), ICT management (Man), and ICT quality (Qua) (Table I). The respondents answered the question: Using a scale of 1 to 5 , state to what extent do you agree that the following situations and phenomena result in the efficient and effective ICT adoption in your enterprise? The scale's descriptions were: 5 - strongly agree, 4 - rather agree, 3 - neither agree nor disagree, 2 - rather disagree, 1 - strongly disagree; and

- The four pillars of sustainable development i.e., ecological (Ecl), economic (Eco), socio-cultural (Soc),

TABLE II.

THE LEVELS OF ICT ADOPTION AND SUSTAINABLE DEVELOPMENT IN THE ENTERPRISES' CONTEXT (N=394)

\begin{tabular}{|c|c|c|c|c|c|c|c|c|c|}
\hline Pillar & Mean & Q25 & MDN & Q75 & VAR & SD & $\mathrm{CV}$ in $\%$ & SK & $\mathbf{C K}$ \\
\hline \multicolumn{10}{|c|}{ ICT adoption pillars } \\
\hline Out & 3.78 & 3.33 & 4.00 & 4.33 & 0.71 & 0.84 & 22.33 & -0.78 & 0.35 \\
\hline $\mathrm{Cul}$ & 3.71 & 3.22 & 3.78 & 4.33 & 0.57 & 0.75 & 20.32 & -0.46 & -0.35 \\
\hline Man & 3.58 & 3.10 & 3.60 & 4.20 & 0.62 & 0.79 & 22.07 & -0.55 & -0.17 \\
\hline Qua & 3.60 & 3.00 & 3.75 & 4.25 & 0.74 & 0.86 & 23.95 & -0.56 & -0.22 \\
\hline \multicolumn{10}{|c|}{ Sustainable development pillars } \\
\hline Ecl & 3.44 & 3.00 & 3.50 & 4.00 & 1.03 & 1.01 & 29.48 & -0.40 & -0.58 \\
\hline Eco & 3.68 & 3.25 & 3.75 & 4.25 & 0.62 & 0.79 & 21.38 & -0.78 & 0.65 \\
\hline Soc & 3.51 & 3.00 & 3.75 & 4.25 & 0.78 & 0.88 & 25.14 & -0.46 & -0.35 \\
\hline Pol & 3.44 & 3.00 & 3.50 & 4.00 & 1.02 & 1.01 & 29.41 & -0.47 & -0.47 \\
\hline
\end{tabular}

Note: mean, median (MDN), first quartile (Q25), third quartile (Q75), variance (VAR), standard deviation (SD), coefficient of variation (CV), skewness (SK), and coefficient of kurtosis (CK).

Source: [2]

The present study examines and evaluates particular parameters shaping each of ICT adoption and sustainable development pillars in the context of Polish enterprises. It focuses on addressing the following two research question:

RQ1: What is the level of ICT adoption in Polish enterprises?

RQ2: What is the level of sustainable development in the context of Polish enterprises? and political sustainability (Pol) (Table I). The respondents answered the question: Using a scale of 1 to 5 , evaluate the following benefits for your enterprise resulting from the efficient and effective ICT adoption? The scale's descriptions were: 5 - strongly large, 4 rather large, 3 - neither large nor disagree, 2 - rather small, 1 - strongly small. 


\section{B. Research subjects and procedure}

In April 2016, the pilot study was conducted to verify the survey questionnaire. Ten experts participated in the study i.e., five researchers in business informatics and five managers from five enterprises - leaders in the ICT application. Finishing touches were put into the questionnaire, especially of a formal and technical nature. No substantive amendments were required.

The subjects in the study were enterprises from the Silesian Province in Poland. The choice of this region was driven by the fact of its continuous and creative transformations related to restructuring and reducing the role of heavy industry in the development of research and science, supporting innovation, using know-how and transferring new technologies, as well as increasing importance of services. In response to the changing socioeconomic and technological environment intensive work on the development of the information society has been undertaken in the region for several years. In the next development strategies of the information society it was and is assumed that the potential of the region, especially in the design, provision and use of advanced information and communication technologies will be increased [46]. All this means that the results of this research can be reflected in innovative efforts to build a sustainable information society in the region and, at the same time, constitute a modus operandi for other regions throughout the country and other countries.

Selecting a sample is a fundamental element of a positivistic study [47]. The stratified sampling and snowball sampling were therefore used to obtain the sample that can be taken to be true for the whole population. The strata were identified based on enterprise's size (defined in terms of the number of employees), economy sector, and type of business activity (defined in terms of related to ICT and non-ICT activities).

The subjects were advised that their participation in completing the survey was voluntary. At the same time, they were assured anonymity and guaranteed that their responses would be kept confidential.

\section{Data collection}

Having applied the Computer Assisted Web Interview and employed the SurveyMonkey platform, the survey questionnaire was uploaded to the website. The data were collected during a two-month period of intense work, between May 12, 2016 and July 12, 2016. After screening the responses and excluding outliers, there was a final sample of 394 usable, correct, and complete responses. The sample error for an infinite population was of about $5 \%$ for a confidence level $97 \%(\mathrm{p}=\mathrm{q}=0.5)$ which previous studies have suggested as acceptable [48], [49]. Additionally, it presented a successful representation of the different business types, economy sectors and size categories.
Table III provides details about enterprise's size, type of the business activities, and economy sector.

TABLE III.

ANALYSIS OF ENTERPRISES PROFILES (N=394)

\begin{tabular}{|l|c|c|}
\hline Characteristics & Frequency & Percentage \\
\hline Number of employees & 78 & $19.80 \%$ \\
\hline 250 and above (large) & 83 & $21.07 \%$ \\
\hline $50-249$ (medium) & 122 & $30.96 \%$ \\
\hline $10-49$ (small) & 111 & $28.17 \%$ \\
\hline less than 10 (micro) & 27 & $6.85 \%$ \\
\hline Economy sector & 83 & $21.07 \%$ \\
\hline $\begin{array}{l}\text { I sector - producing raw material and } \\
\text { basic foods }\end{array}$ & 238 & $60.40 \%$ \\
\hline $\begin{array}{l}\text { II sector - manufacturing, processing, } \\
\text { and construction }\end{array}$ & 46 & $11.68 \%$ \\
\hline $\begin{array}{l}\text { III sector - providing services to the } \\
\text { general population and to } \\
\text { businesses }\end{array}$ & 136 & $34.52 \%$ \\
\hline $\begin{array}{l}\text { IV sector - including intellectual } \\
\text { activities }\end{array}$ & 258 & $65.48 \%$ \\
\hline Business activities & \multicolumn{2}{|l}{} \\
\hline ICT (manufacturing, trade, services) & \multicolumn{2}{|l|}{} \\
\hline No ICT &
\end{tabular}

Source: own elaboration.

\section{Data analysis}

The data were stored in Microsoft Excel format. Using Statistica package and Microsoft Excel, the data were analyzed. The descriptive statistical analysis was employed to describe the levels of ICT adoption and sustainable development parameters within enterprises. The following statistics were calculated: mean, median (MDN), first quartile (Q25), third quartile (Q75), mode, variance (VAR), standard deviation (SD), coefficient of variation (CV), skewness (SK), and coefficient of kurtosis (CK).

\section{RESEARCH FINDINGS}

\section{A. The level of ICT adoption within enterprises}

In order to answer the research question RQ1: What is the level of ICT adoption in Polish enterprises?, a detailed descriptive analysis was conducted. The results are presented in Table IV.

It has been found that the average levels of ICT adoption parameters ranged from 3.24 to 4.22 (on a 5-point scale from 1.00 to 5.00). The median values were in the range between 3.00 and 5.00 , whereas the mode values were 4 or 5 . On average, the highest levels are specific for parameters related mainly to three ICT adoption pillars i.e., information culture, ICT management, and ICT outlay.

The highest ranked parameters of ICT adoption were (Table IV): 
TABLE IV.

THE LEVELS OF ICT ADOPTION PARAMETERS IN THE ENTERPRISES' CONTEXT (N=394)

\begin{tabular}{|c|c|c|c|c|c|c|c|c|c|}
\hline Parameters & Mean & Q25 & MDN & Q75 & Mode & $\begin{array}{c}\text { Sample } \\
\text { volume for } \\
\text { Mode }\end{array}$ & VAR & SD & $\mathrm{CV}$ in \% \\
\hline Out1 & 3.98 & 4 & 4 & 5 & 4 & 158 & 1.18 & 1.09 & 27.27 \\
\hline Out2 & 3.71 & 3 & 4 & 5 & 4 & 165 & 1.27 & 1.13 & 30.37 \\
\hline Out3 & 3.64 & 3 & 4 & 5 & 4 & 132 & 1.54 & 1.24 & 34.14 \\
\hline Cul4 & 4.20 & 4 & 5 & 5 & 5 & 207 & 1.16 & 1.08 & 25.62 \\
\hline Cul5 & 4.22 & 4 & 4 & 5 & 5 & 186 & 0.92 & 0.96 & 22.73 \\
\hline Cul6 & 3.53 & 2 & 4 & 5 & 4 & 127 & 1.62 & 1.27 & 36.12 \\
\hline Cul7 & 3.47 & 2 & 4 & 4 & 4 & 142 & 1.58 & 1.26 & 36.26 \\
\hline Cul8 & 3.28 & 2 & 3 & 4 & 4 & 139 & 1.30 & 1.14 & 34.77 \\
\hline Cul9 & 3.85 & 3 & 4 & 5 & 4 & 170 & 1.22 & 1.10 & 28.73 \\
\hline Cul10 & 3.91 & 4 & 4 & 5 & 4 & 192 & 0.98 & 0.99 & 25.34 \\
\hline Cul11 & 3.58 & 3 & 4 & 4 & 4 & 188 & 1.21 & 1.10 & 30.70 \\
\hline Cul12 & 3.37 & 2 & 4 & 4 & 4 & 142 & 1.57 & 1.25 & 37.16 \\
\hline Man13 & 3.53 & 3 & 4 & 4 & 4 & 165 & 1.27 & 1.13 & 32.00 \\
\hline Man14 & 3.61 & 3 & 4 & 4 & 4 & 181 & 1.11 & 1.05 & 29.18 \\
\hline Man15 & 3.60 & 3 & 4 & 4 & 4 & 152 & 1.43 & 1.20 & 33.28 \\
\hline Man16 & 3.52 & 2 & 4 & 5 & 4 & 145 & 1.64 & 1.28 & 36.40 \\
\hline Man17 & 3.68 & 3 & 4 & 4 & 4 & 171 & 1.25 & 1.12 & 30.36 \\
\hline Man18 & 3.47 & 3 & 4 & 4 & 4 & 157 & 1.36 & 1.17 & 33.60 \\
\hline Man19 & 3.88 & 3 & 4 & 5 & 4 & 160 & 1.27 & 1.13 & 29.05 \\
\hline Man20 & 3.92 & 3 & 4 & 5 & 4 & 148 & 1.24 & 1.11 & 28.36 \\
\hline Man21 & 3.25 & 2 & 3 & 4 & 4 & 122 & 1.60 & 1.27 & 38.93 \\
\hline Man22 & 3.33 & 2 & 3 & 4 & 4 & 125 & 1.40 & 1.18 & 35.48 \\
\hline Qua23 & 3.66 & 3 & 4 & 5 & 4 & 151 & 1.49 & 1.22 & 33.34 \\
\hline Qua24 & 3.68 & 3 & 4 & 4 & 4 & 170 & 1.25 & 1.12 & 30.43 \\
\hline Qua25 & 3.71 & 3 & 4 & 5 & 4 & 161 & 1.25 & 1.12 & 30.10 \\
\hline Qua26 & 3.77 & 3 & 4 & 5 & 5 & 132 & 1.44 & 1.20 & 31.78 \\
\hline Qua27 & 3.75 & 3 & 4 & 5 & 4 & 142 & 1.50 & 1.22 & 32.67 \\
\hline Qua28 & 3.53 & 3 & 4 & 4 & 4 & 160 & 1.42 & 1.19 & 33.73 \\
\hline Qua29 & 3.44 & 2 & 4 & 4 & 4 & 130 & 1.57 & 1.25 & 36.52 \\
\hline Qua30 & 3.24 & 2 & 4 & 4 & 4 & 134 & 1.69 & 1.30 & 40.20 \\
\hline
\end{tabular}

Note: mean, median (MDN), first quartile (Q25), third quartile (Q75), variance (VAR), standard deviation (SD), coefficient of variation (CV), skewness (SK), and coefficient of kurtosis (CK).

$-\operatorname{Cul5}($ mean $=4.22, \mathrm{MDN}=4$, mode $=5)$ and Cul4 $($ mean $=4.20, \mathrm{MDN}=5$, mode $=5$ ). It means that digital competences of enterprises' employees and managers are relatively high. Managers and employees are able to operate a computer and the Internet, use a different kind of software and applications, search for information, use it and evaluate its usefulness, as well as creatively, efficiently and effectively use ICT so as to achieve a variety of business benefits;

- Cul10 (mean $=3.91, \mathrm{MDN}=4$, mode $=5$ ) and Cul9 (mean $=3.85, \mathrm{MDN}=4$, mode $=4$. It means that sociocultural competences of enterprises' employees and managers are also relatively high. Managers and employees are open to change and novelties, can negotiate, integrate the team and build confidence, are able to manage a group as well as a multicultural team, know how to build varied relationships and networks, share knowledge and are able to manage knowledge;

- Out1 (mean $=3.98, \mathrm{MDN}=4$, mode $=4)$. It means that enterprises' financial capabilities ensure the purchase and use of computer hardware, software, the Internet, telecommunications and improvement of digital literacy;

- Man20 (mean = 3.92, MDN = 4; mode = 4). It means that enterprises implement and apply the law regulations associated with ICT adoption, in particular related to electronic invoicing, electronic signatures, data protection, electronic services, protection of databases, distance contracts;

- Man19 $($ mean $=3.88, \mathrm{MDN}=4$; mode $=4)$. It means that enterprises develop and apply regulations and tools 
on information security and protection of personal data, also associated with ICT adoption in terms of intraenterprise and inter-enterprise (e.g., in relations with customers and business partners).

Furthermore, the lowest levels of ICT adoption were mainly related to ICT quality and ICT management (Table IV):

- Qua30 (mean = 3.24, $\mathrm{MDN}=4$, mode $=4)$. It means that many enterprises did not implement any BI system and do not employ any business analyses e.g., sales, customers, financial, marketing, products analyses. In general, $25 \%$ of enterprises assessed BI adoption at a level not higher than 2.00 and $75 \%$ of enterprises - at a level not higher than 4.00. Coefficient of variation with the value above $40 \%$ shows substantial differences in BI adoption within enterprises.

- Qua29 (mean = 3.44, MDN = 4, mode =4). It means that many enterprises did not implement any ERP system(or any integrated domain-specific systems) which provides a coherent, comprehensive and integrated support for business processes in the whole range of business activities, and supports the primary and secondary business processes, such as sales, purchasing, marketing, distribution, customer service, warehouse management, human resources and payroll, or finance and accounting;

- Man21 (mean = 3.25, $\mathrm{MDN}=3$, mode $=4$ ) concerning the implementation and apply of ICT within enterprises arising from ICT public projects, coordinated and implemented at national, regional and/or local level e.g., the construction of broadband networks, making electronic platforms of public services available etc.;

- Man18 (mean =3.47, MDN =4, mode =4). It means that a lot of enterprises did not implement the latest management concepts, such as process approach, knowledge management, risk management, change management, quality management, customer relationship management, trust management, human resource management, networking approach.

In general, the level of ICT outlay was the highest within enterprises, followed by the level of information culture. The levels of ICT management and ICT quality were the lowest (Table II).

\section{B. The level of sustainable development in the enterprises' context}

In order to answer the research question $R Q 2$ : What is the level of sustainable development in the context of Polish enterprises?, a detailed descriptive analysis was conducted. The results are presented in Table V.

It has been found that the average levels of sustainable development parameters ranged from 3.25 to 3.96 (on a 5point scale from 1.00 to 5.00). The median and mode values were 4.00 except for Pol15 with the $\mathrm{MDN}=3.00$. On average, the highest levels are mainly specific for parameters related to economic sustainability, whereas a parameter of political sustainability was ranked the lowest. The highest ranked parameters of sustainability were (Table V):

TABLE V.

THE LEVELS OF SUSTAINABLE DEVELOPMENT PARAMETERS IN THE ENTERPRISES' CONTEXT (N=394)

\begin{tabular}{|l|c|c|c|c|c|c|c|c|c|}
\hline Parameters & Mean & Q25 & MDN & Q75 & Mode & $\begin{array}{c}\text { Sample } \\
\text { volume for } \\
\text { Mode }\end{array}$ & VAR & SD & CV in \% \\
\hline Ec11 & 3.38 & 2 & 4 & 4 & 4 & 149 & 1.21 & 1.10 & 32.53 \\
\hline Ec12 & 3.50 & 2 & 4 & 4 & 4 & 160 & 1.40 & 1.18 & 33.82 \\
\hline Eco3 & 3.48 & 3 & 4 & 4 & 4 & 166 & 1.24 & 1.11 & 31.99 \\
\hline Eco4 & 3.67 & 3 & 4 & 4 & 4 & 168 & 1.11 & 1.05 & 28.70 \\
\hline Eco5 & 3.54 & 3 & 4 & 4 & 4 & 163 & 1.36 & 1.17 & 32.95 \\
\hline Eco6 & 3.51 & 3 & 4 & 4 & 4 & 159 & 1.31 & 1.14 & 32.62 \\
\hline Eco7 & 3.96 & 4 & 4 & 5 & 4 & 180 & 1.01 & 1.00 & 25.35 \\
\hline Eco8 & 3.89 & 4 & 4 & 5 & 4 & 185 & 1.03 & 1.02 & 26.09 \\
\hline Eco9 & 3.68 & 3 & 4 & 5 & 4 & 150 & 1.27 & 1.13 & 30.64 \\
\hline Eco10 & 3.74 & 3 & 4 & 5 & 4 & 165 & 1.14 & 1.07 & 28.50 \\
\hline Soc11 & 3.76 & 3 & 4 & 4 & 4 & 181 & 1.01 & 1.00 & 26.74 \\
\hline Soc12 & 3.45 & 2 & 4 & 4 & 4 & 144 & 1.52 & 1.23 & 35.70 \\
\hline Soc13 & 3.47 & 2 & 4 & 4 & 4 & 150 & 1.50 & 1.23 & 35.29 \\
\hline Soc14 & 3.38 & 2 & 4 & 4 & 4 & 153 & 1.26 & 1.12 & 33.29 \\
\hline Pol15 & 3.25 & 2 & 3 & 4 & 4 & 148 & 1.32 & 1.15 & 35.40 \\
\hline Pol16 & 3.63 & 3 & 4 & 4 & 4 & 178 & 1.24 & 1.11 & 30.61 \\
\hline
\end{tabular}

Note: mean, median (MDN), first quartile (Q25), third quartile (Q75), variance (VAR), standard deviation (SD), coefficient of variation (CV), skewness (SK), and coefficient of kurtosis (CK). 
- Eco7 $($ mean $=3.96, \mathrm{MDN}=4$, mode $=4)$. It means that the improvement of efficiency and effectiveness of customer services resulting of ICT adoption was evaluated relatively high by enterprises;

- Eco8 (mean = 3.96, $\mathrm{MDN}=4$, mode = 4). It means that thanks to ICT adoption the enterprise achieves better and more efficient organization of work resulting from improvements and automation of business processes, communication, collaboration and networking within the enterprise and in its relations with its stakeholders (customers, suppliers, partners), facilitating access to information;

- Eco10 (mean = 3.74, $\mathrm{MDN}=4$, mode =4). It means that the improvement of customer satisfaction and loyalty from products and services offered to them by the enterprise as well as pre- and post-sales support resulting from ICT adoption was assessed relatively high by enterprises;

- Eco9 $($ mean $=3.68, \mathrm{MDN}=4$, mode = 4). It means that the result of ICT adoption by enterprise is to acquire new customers and markets, including foreign ones e.g., through internet marketing, online sales, obtaining information on markets and customers;

- Soc11 (mean = 3.76, MDN = 4, mode =4). It means that ICT adoption by enterprise allows to extend knowledge and skills already held by employees and acquire new ones (including digital knowledge and skills), as well as better align thinking and action in response to the changing reality, legal requirements and customer needs.

Furthermore, the lowest level of sustainability was related to political, ecological, and socio-cultural sustainability (table V):

- Pol15 (mean = 3.25, MDN =4, mode =4). It means that enterprises' participation in the public consultation and democratic public decision-making as well as development of cooperation, communication, partnerships and networks between enterprises and public administration were assessed relatively very low;

- Ecl1 (mean = 3.38, MDN =4, mode =4). It means that a lot of enterprises did not achieve lower average annual energy consumption and increased protection of the environment through ICT consuming less energy and built with fewer materials (miniaturization), and more easily recyclable and disposable;

- Soc14 (mean = 3.38, MDN = 3, mode =4). It means that reducing social exclusion due to age, education, place of residence or disability, by facilitating access to the enterprise, its products/services and jobs was ranked relatively very low.

On average, the level of economic sustainability was the highest, whereas the levels of ecological and political sustainability were the lowest (Table II).

\section{V.CONCLUSIONS}

\section{A. Research contribution}

Although the literature review suggested that the phenomenon of ICT adoption for sustainable development had been previously examined [6], [11], [12], [16], [32], [35], this study extended previous research on the contribution of ICT adoption by enterprises to sustainable development [1]-[3]. and indicated the levels of ICT adoption and sustainable development in-depth. It contributes to the existing research on sustainable information society, ICT adoption, and sustainable development, in particular in the enterprises' context by:

- indicating and assessing the level of ICT adoption, especially in terms of ICT outlay, information culture, ICT management, and ICT quality; and

- indicating and assessing the level of sustainable development, especially in terms of ecological, economic, socio-cultural, and political sustainability.

Firstly, this study indicated that ICT outlay was at the highest level followed by information culture, whereas the lowest and similar levels were specific to ICT management and ICT quality. Digital and socio-cultural competences of employees and managers, financial capabilities ensuring any ICT projects as well as law regulations associated with ICT adoption and information security were relatively highly ranked by enterprises. However, the lowest level was specific for BI and ERP system adoption as well as the adoption of latest management concepts and exploitation of synergies between national ICT projects and own ones. All these require to improve ICT adoption, mainly its quality and management pillars.

Secondly, the outcomes showed that economic sustainability was at the highest level, whereas the lowest and similar levels were specific to ecological and political sustainability. The improvement of efficiency and effectiveness of customer services, better and more efficient organization of work, the enhancement of customer satisfaction and loyalty as well as the increase of new customers and markets as a result of ICT adoption were evaluated relatively high by enterprises. However, the lowest level was specific for enterprises' participation in the democratic public decision-making as well as energy savings and environment protection were assess relatively very low. It means that enterprises reap more economic benefits than ecological and political ones from adopting ICT. It is, therefore, required to increase ecological and political sustainability through ICT adoption.

\section{B. Research implication for research and practice}

While this research is exploratory, it should provide a valuable foundation for further work examining ICT adoption, sustainable development, and a synergy between them more widely. 
Researchers may use the proposed methodology to do similar analyses with different sample groups in other countries, and many comparisons between different countries can be drawn. Moreover, the methodology constitutes a very comprehensive basis for identifying the levels of ICT adoption and sustainable development, as well as the correlations between the two constructs, but researchers may develop, verify and improve this methodology.

This study offers several implications for enterprises. They may find the results appealing and useful in enhancing ICT adoption, experiencing the full potential of ICT adoption, and deriving various benefits from ICT adoption. The results suggest various kinds of advantages like ecological, economic, socio-cultural, and political that can be gained thanks to ICT adoption. In addition, they propose some guidelines on how to effectively and efficiently adopt ICT in order to obtain those advantages. It is evident from the findings that Polish enterprises should devote utmost attention to the enhancement of ICT management and ICT quality. Most of all, this research can be genuinely useful for the transition economies in Central and Eastern Europe. This is because the countries are similar with regard to analogous geopolitical situation, their joint history, traditions, culture and values, the quality of ICT infrastructure, as well as developing democratic state structures and a free-market economy, and participating in the European integration process.

All in all, the research results might provide a partial explanation to the issue of how enterprises can participate in the creation of sustainable development.

\section{Research limitations and future works}

However, as with many other studies, this research looking more than superficially into ICT adoption and sustainable development in the enterprises' context has been limited. First, the ICT adoption and sustainability constructs are new constructs that have yet to be further explored and exposed to repeated empirical validation. Second, the sample consisted of Polish enterprises only, especially from the Silesian Province. The study sample excludes statistical generalization of the results from Silesian enterprises to Polish enterprises. However, previous research into the success factors for and the level of adopting ICT in Poland [50] indicated that there is no difference between enterprises in the Silesia Province and in Poland. Therefore, these research findings cannot be confined only to the Silesian enterprises and can be extended to Polish enterprises. After all, caution should be taken when generalizing the findings to other regions and countries. Finally, the research subjects were limited to enterprises and it is therefore only the standpoint of enterprises toward ICT adoption for achieving sustainable development. Caution should be taken when generalizing the findings to sustainable development in general.
Additional research must be performed to better understand ICT adoption and sustainable development. First, further validation of the levels of ICT adoption and sustainable development should be carried out for a larger sample comprising enterprises from different Polish provinces as well as from other countries. Second, research on the measurement of ICT adoption and sustainability in households and government units should be conducted because they are, besides enterprises, the main stakeholders of SIS.

\section{REFERENCES}

[1] E. Ziemba, "The contribution of ICT adoption to the sustainable information society," Journal of Computer Information Systems, vol. 59, issue $2, \quad$ pp. 116-126, 2019, https://doi.org/10.1080/08874417.2017.1312635.

[2] E. Ziemba, "The ICT adoption in enterprises in the context of the sustainable information society," in Proceedings of the 2017 Federated Conference on Computer Science and Information Systems FedCSIS, M. Ganzha, L. Maciaszek, and M. Paprzycki, Eds., Czech Technical University in Prague, Prague, September 3-6, 2017, p. 1031-1038. https://doi.org/10.15439/2017F89.

[3] E. Ziemba, "Synthetic indexes for a sustainable information society: Measuring ICT adoption and sustainability in Polish enterprises," in Information technology for management: Ongoing Research and Development, E. Ziemba, Ed. Lecture Notes in Business Information Processing, vol. 311, pp. 151-169, 2018. https://doi.org/10.1007/978-3-319-77721-4_9.

[4] S. Sala, F. Farioli, and A. Zamagni, "Progress in sustainability science: lessons learnt from current methodologies for sustainability assessment: Part 1," The International Journal of Life Cycle Assessment, vol. 18, no 781, pp. 1653-1672, 2012. https://doi.org/10.1007/s11367-012-0508-6.

[5] M. Missimer, K.H. Robèrt, and G. Broman, "A strategic approach to social sustainability-Part 2: A principle-based definitions," Journal of Cleaner Production, vol. 149, no 1, pp. 42-52, 2017. https://doi.org/10.1016/j.jclepro.2016.04.059.

[6] T. Schauer, The sustainable information society - vision and risks. Vienna: The Club of Rome - European Support Centre, 2003.

[7] J. Servaes and N. Carpentier, Eds. Towards a sustainable information society. Deconstructing WSIS. Portland: Intellect, 2006.

[8] E. Ziemba, Eds. Towards a sustainable information society: People, business and public administration perspectives. Newcastle upon Tyne: Cambridge Scholars Publishing, 2016.

[9] T. Bisk and P. Bołtuć, "Sustainability as growth," in Technology, society and sustainability. Selected concepts, issues and cases, ed. L.W. Zacher, Ed. Cham: Springer, 2017, pp. 239-250. https://doi.org/10.1007/978-3-319-47164-8_16.

[10] A. Grunwald, "Technology assessment and policy advice in the field of sustainable development," in Technology, society and sustainability. Selected concepts, issues and cases, L.W. Zacher, Ed. Cham: Springer, 2017, pp. 203-221. https://doi.org/10.1007/978-3319-47164-8_14.

[11] L.M. Hilty and B. Aebischer, "ICT for sustainability: An emerging research field," Advances in Intelligent Systems and Computing, vol. 310, pp. 1-34, 2015.

[12] L.M. Hilty and M.D. Hercheui, "ICT and sustainable development, What kind of information society?," in What kind of information society? Governance, virtuality, surveillance, sustainability, resilience, Proceedings of 9th IFIP TC 9 International Conference, HCC9, and 1st IFIP TC 11 International Conference, J. Berleur, M.D. Hercheui, and L.M. Hilty, Eds., Brisbane. September 20-23, 2010, p. 227-235.

[13] J.W. Houghton, "ICT and the environment in developing countries: A review of opportunities and developments," in What kind of information society? Governance, virtuality, surveillance, sustainability, resilience, Proceedings of 9th IFIP TC 9 International Conference, HCC9, and 1st IFIP TC 11 International Conference, 
J. Berleur, M.D. Hercheui, and L.M. Hilty, Eds., Brisbane, September 20-23, 2010, p. 236-247.

[14] R.T. Watson, M.C. Boudreau, A.J. Chen, and M. Huber, "Green IS: Building sustainable business practices," in Information systems, R.T. Watson, Ed. Athens: Global Text Project, 2008, pp. 247-261.

[15] V. Kodakanchi, E. Abuelyaman, M.H.S. Kuofie, and J. Qaddour, "An economic development model for IT in developing countries," The Electronic Journal of Information Systems in Developing Countries, vol. 28, no 7, pp. 1-9, 2006.

[16] M.G. Guillemette and G. Paré, "Toward a new theory of the contribution of the IT function in organizations," $M I S Q$, (36:2), 2012, pp. 529-551.

[17] ITU, Measuring the Information Society Report. Geneva: International Telecommunication Union, 2017. https://www.itu.int/en/ITU-

D/Statistics/Documents/publications/misr2017/MISR2017_Volume1. pdf (accessed: 12th April 2019).

[18] WEF, Networked Readiness Index. World Economic Forum, 2019. http://reports.weforum.org/global-information-technology-report2016/networked-readiness-index/ (accessed: 12th April 2019).

[19] Eurostat, Sustainable development in the European Union. Monitoring report on progress. Towards the SDGS in an EU context. Luxembourg: Publications Office of the European Union, 2018. https://ec.europa.eu/eurostat/documents/3217494/9237449/KS-01-18656-EN-N.pdf/2b2a096b-3bd6-4939-8ef3-11cfc14b9329 (accessed: 12th April 2019).

[20] OECD, Measuring distance to the SDG targets. An assessment of where OECD countries stand. OECD, 2017. https://www.oecd.org/sdd/OECD-Measuring-Distance-to-SDGTargets.pdf (accessed: 12th April 2019).

[21] WCED, Our common future. New York: Oxford University Press, 1987.

[22] New

Oxford American

Dictionary, https://en.oxforddictionaries.com/definition/sustainable (accessed: 12th April 2019).

[23] P. Becker, Sustainability Science. Managing Risk and Resilience for Sustainable Development. Elsevier B.V., 2014. https://doi.org/10.1016/B978-0-444-62709-4.00005-1.

[24] M. Zemigala, "Tendencies in research on sustainable development in management sciences," Journal of Cleaner Production, vol. 218, pp. 796-809, 2019. https://doi.org/10.1016/j.jclepro.2019.02.009.

[25] R. Axelsson, P. Angelstam, E. Degerman, S. Teitelbaum, K. Andersson, M. Elbakidze, and M.K. Drotz, "Social and cultural sustainability: Criteria, indicators, verifier variables for measurement and maps for visualization to support planning," $A M B I O$, vol. 42, pp. 215-228, 2013. https://doi.org/10.1007/s13280-012-0376-0.

[26] K. Soini and J. Dessein J. "Culture-sustainability relation: Towards a conceptual framework", Sustainability, vol. 8, no. 2, paper 167, 2016. https:/doi.org/10.3390/su8020167.

[27] R. Khan, "How frugal innovation promotes social sustainability," Sustainability, vol. 8, no 10, paper 1034, 2016. https://doi.org/10.3390/su8101034

[28] A.H. Huang, "A model for environmentally sustainable information systems development," Journal of Computer Information Systems, vol. 49, no 4, pp. 114-121, 2009.

[29] B. Moldan, S. Janoušková, and T. Hák, "How to understand and measure environmental sustainability: Indicators and targets," Ecological Indicators, vol. 17, pp. 4-13, 2012.

[30] M.G. Guillemette and G. Paré, "Transformation of the information technology function in organizations: A Case study in the manufacturing sector," Canadian Journal of Administrative Sciences, vol. 29, pp. 177-190, 2012.

[31] T. Hameed, ICT as an enabler of socio-economic development Daejeon: Information \& Communications University, 2015, http://www.itu.int/osg/spu/digitalbridges/materials/hameed-paper.pdf, (accessed: 12th June 2016).
[32] B. Donnellan, C. Sheridan, and E. Curry, "A capability maturity framework for sustainable information and communication technology," IT Professional, vol. 13, no 1, pp. 33-40, 2011.

[33] P. Palvia, N. Baqir, and H. Nemati, "ICT for socio-economic development: A citizens' perspective," Information \& Management, vol.55, pp. 160-176, 2018. https://doi.org/10.1016/j.im.2017.05.003

[34] N. Roztocki and H.R. Weistroffer, "Conceptualizing and researching the adoption of ict and the impact on socioeconomic development," Information Technology for Development, vol. 22, no. 4, pp. 541549, 2016. http://dx.doi.org/10.1080/02681102.2016.1196097

[35] E. Curry and B. Donnellan, "Understanding the maturity of sustainable ICT," in Green business process management - Towards the sustainable enterprise, J. vom Brocke, S. Seidel, and J. Recker, Eds. Berlin: Springer, 2012, pp. 203-216.

[36] R. Ryssel, T. Ritter, and H.G. Gemunden, "The impact of information technology deployment on trust, commitment and value creation in business relationships," Journal of Business \& Industrial Marketing, vol. 19, no. 3, pp. 197-207, 2004.

[37] S. Reino, A.J. Frew, and C. Albacete-Sáez, "ICT adoption and development: issues in rural accommodation," Journal of Hospitality and Tourism Technology, vol. 2, issue 1, pp. 66-80, 2011. https://doi.org/10.1108/17579881111112421

[38] G. Battisti, and P. Stoneman, "Inter- and intra-firm effects in the diffusion of new process technology," Research Policy, vol. 32, no. 9, pp. 1641-55, 2003.

[39] T. Niebel, "ICT and economic growth - Comparing developing, emerging and developed countries," World Development, vol. 104, pp. 197-211, 2018. https://doi.org/10.1016/j.worlddev.2017.11.024.

[40] K.M. Vu, 2013. Information and communication technology (ICT) and Singapore's economic growth," Information Economics and $\begin{array}{lllll}\text { Policy, } & \text { vol. } 25, & \text { pp. 284-300, } 2013 .\end{array}$ http://dx.doi.org/10.1016/j.infoecopol.2013.08.002

[41] EITO, The impact of ICT on sustainable development. European Information Technology Observatory and Forum for the Future, 2002. http://homepage.cs.latrobe.edu.au/sloke/greenIT/eito_forum_2002.pdf (accessed: 12th April 2019).

[42] P.R. Hinton, C. Brownlow, I. McMurvay, and B. Cozens, SPSS Explained. East Sussex: Routledge, 2004.

[43] D. Gefen and D. Straub, "A practical guide to factorial validity using PLS-graph: Tutorial and annotated example," Communications of the Association for Information Systems, vol. 16, no 5, pp. 91-109, 2005.

[44] J. Hulland, "Use of Partial Least Squares (PLS) in strategic management research: A review of four recent studies," Strategic Management Journal, vol. 20, no 2, p. 195-204, 1999.

[45] T.A. Brown, Confirmatory factor analysis for applied research. Guilford Press, 2006.

[46] ŚCSI, Strategia rozwoju spoleczeństwa informacyjnego województwa ślaskiego do roku 2015 [Strategy of information society development in Upper Silesia region]. Katowice: Śląskie Centrum Społeczeństwa Informacyjnego, 2009, http://www.e-slask.pl/article/strategia_rozwoju _spoleczenstwa_informacyjnego_wojewodztwa_slaskiego_do_roku_2 015, (accessed: 12th June 2016).

[47] J. Collis and R. Hussey, Business research. A practical guide for undergraduate and postgraduate students. New York: Palgrave Macmillan, 2003.

[48] D. Gilliland and V. Melfi, "A note on confidence interval estimation and margin of error," Journal of Statistics Education, vol. 18, no 1, pp. 1-8 (2010). www.amstat.org/publications/jse/v18n1/gilliland.pdf (accessed: 19th April 2019).

[49] R.J. Thornton and J.A. Thornton, "Erring on the margin of error," Southern Economic Journal, vol. 71, no. 1, pp. 130-135, 2004. https://www.jstor.org/stable/4135315.

[50] E. Ziemba, Eds. Czynniki sukcesu i poziom wykorzystania technologii informacyjno-komunikacyjnych $w$ Polsce [Success factors for and level of ICT adoption in Poland]. Warsaw: CeDeWu, 2015. 